\title{
CROSS-BORDER COOPERATION DEVELOPMENT OF UKRAINE: FORMS AND INSTRUMENTS OF COMPETITIVENESS INCREASE
}

\author{
Yurii Sotnikov ${ }^{1}$, Ievgen Kravchenko ${ }^{2}$ \\ ${ }^{1,2}$ Odessa National Economic University, Ukraine \\ cross $^{r e f}$ http://dx.doi.org/10.5755/j01.em.18.1.4379
}

\begin{abstract}
The article describes the state of cross-border cooperation in Ukraine and proposes new forms and instruments of cross-border cooperation development, aimed at increasing the competitiveness of Ukrainian border regions. Such innovative forms as cross-border cluster, crossborder industrial zone and European groupings of territorial cooperation have the key role in the paper.
\end{abstract}

The type of the article: Theoretical article.

Keywords: cross-border cooperation development, cross-border cluster, cross-border industrial zone, competitiveness.

JEL Classification: F02, F23, F63.

\section{Introduction}

Introduce the problem. After Ukraine made a pro-European choice, the EU integration has become the strategic course of its foreign policy. Once the Partnership and Cooperation Agreement between the European Union and Ukraine has entered into force, it formed the basis for Ukraine's EU integration strategy. Cross-border cooperation is considered to be one of the key areas of Ukraine's integration into the European structures, as well as a promising direction of international integration in general. Areas of cross-border cooperation include development of the border infrastructure, tourism and recreation, ecology and environment, crime control, cultural exchange etc. A new milestone in the development of Ukrainian cross-border cooperation has been reached once the European Neighbourhood policy was extended to Ukrainian territory. This policy offered a wide range of interaction mechanisms, thus opening great prospects for economic integration. That's why it is important to know the forms and instruments of cross-border cooperation development and to introduce innovative flows within the considered sphere.

Develop the background. Problems of regional development and cross-border cooperation have been studied by many foreign academics and have recently become a subject of Ukrainian researchers' interest. The cross-border cooperation issue has been studied by such foreign scholars as Lehner (1995); Andersson, Schwaag-Serger, Sorvik, Hansson (2004); Porter (1998) and Ukrainian ones: Amosha and Lyashenko (2008); Mikula (2004); Kish (2008); Sabluk, Kropyvko (2010); Varnaliy (2007); Voloshin, Vasyltsiv, Borschevsky, Babets, Zasadko, Mihuschenko (2011).

However, the impact of the forms and instruments of cross-border cooperation on Ukrainian regional competitiveness has been poorly researched, considering the current European integration processes and Ukraine's participation in them.

State the purpose and rationale background. The purpose of this research is to study the influence of the forms and instruments of cross-border cooperation development on the formation of the Ukrainian regional competitiveness, as well as to identify and explore its potential benefits. It plays an important role within Ukraine's integration direction. 


\section{Method}

Referring to the studies of the foreign and Ukrainian scientists, the analysis and the synthesis of literature, the data was systematized and the classification of new forms of cross-border cooperation was created.

In order to provide the reliability and validity of the results of research and to achieve the objectives of the paper we used following methods: the dialectic method - to justify the preconditions for the study of cross-border cooperation in Ukraine, the analysis and synthesis methods - to study the conceptual and the categorical apparatus, and the "cross-border cooperation" term, the theoretical synthesis and the formal logic methods - to study the international and domestic experience in the application forms and instruments of cross-border cooperation and the graphical method - for a schematic representation of the theoretical and practical research results.

Thus, the usage of mentioned-above methods allows understanding the cross-border cooperation, its forms and the role in modern international economic system.

Current state of international economic relations necessitates the search for the new forms of cross-border cooperation in order to increase its efficiency and the competitiveness of the regions that take part in it. The term "Cross-border cooperation" means a joint action aimed at the establishing and deepening the economic, social, scientific, technical, environmental, cultural and other relations between local communities and their representative bodies, as well as local executive authorities and relevant authorities of other states within the competence defined by their national legislation. (Law of Ukraine for "Cross-border cooperation", 2004). In addition to the abovementioned objectives, the cross-border cooperation also plays the role of "growth pulse (potential)" and cross-border regions, respectively, are the "poles of growth" (see Figure 1). If we illustrate social and economic development moving from West to East, from more to less developed economic environment (see Fig.1) and note that in each i-country it progresses from centre (Si) to the periphery ( $\mathrm{Ai}$ and $\mathrm{Bi}$ ), then we can see that cross-border cooperation creates additional opportunities for mobilizing the territorial resources (AiAi' and $\mathrm{BiBi}$ ) in order to accelerate its socioeconomic development and to improve the quality of life.

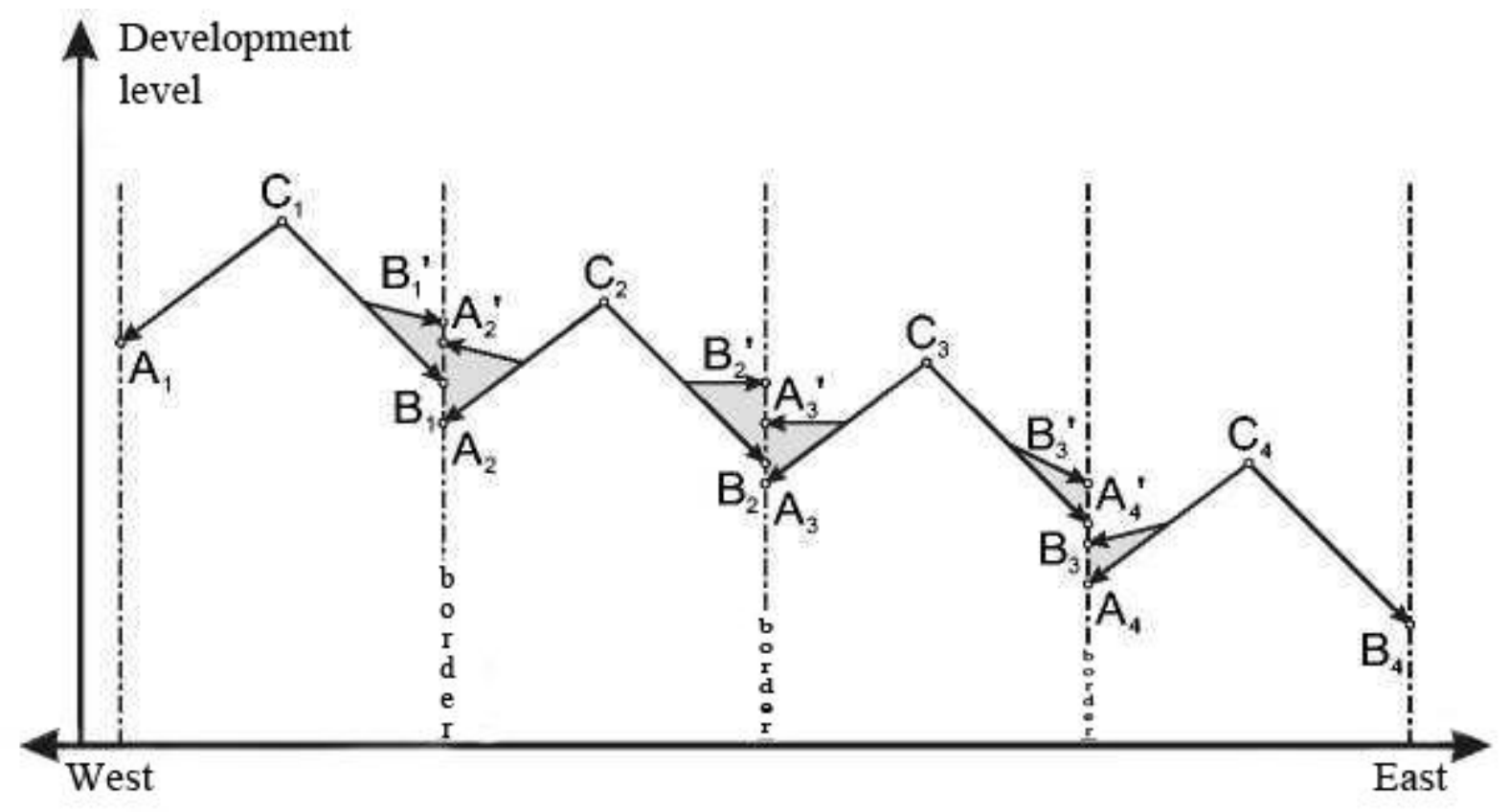

Figure 1. The role of cross-border cooperation in regional development (Varnaliy, 2007)

This figure shows that resource potential of border regions (shaded triangle) can significantly accelerate their development through cooperation by uniting their potentials and forming a more advanced society. Assuming that the potential of border areas is different within the 
borders of considered state, as well as its neighbours (i.e. $\mathrm{AiAi}{ }^{\prime}=\mathrm{BiBi}$ and $\mathrm{BiBi}{ }^{\prime}=\mathrm{Ai}+1 \mathrm{~A} i+1$ ), development will be stimulated by the sum of $\mathrm{AiAi}+\mathrm{BiBi}$ ' which will be adjusted by the $\lambda$ factor - activeness of cross-border cooperation. A certain analogy can be drawn with the basic tenets of the boundary processes theory. On one hand, cross-border cooperation is increasing border capacity and on the other - it's eliminating the existence of the border, reducing its barrier function (Varnaliy, 2007).

Moreover, cross-border cooperation can reverse the trend of regional development "from centre to periphery" and erase the analogies between "border", "peripheral" and "underdeveloped". In other words, we can agree with J.-P. Lehner who said that "...cross-border regions allow to change a peripheral situation into a central one" (Lehner, 1995).

\section{Results}

In order to ensure the getting benefits from the cross-border cooperation development by Ukraine and its border regions, it is necessary to consider the forms of cross-border cooperation.

There are several typical forms of cross-border cooperation. The most important role between them plays the euroregion, which can be created through agreements on cross-border cooperation in specific areas, by establishing mutually beneficial contacts between businesses on different sides of the border (Law of Ukraine for "Cross-border cooperation", 2004).

Nowadays, the important role in the competitiveness increase of Ukraine's border regions start to play the new forms of cross-border cooperation. The main objective of the new forms of cross-border cooperation is to accelerate growth by combining the efforts of participants, providing competitive advantages for cross-border regions (see Figure 2).

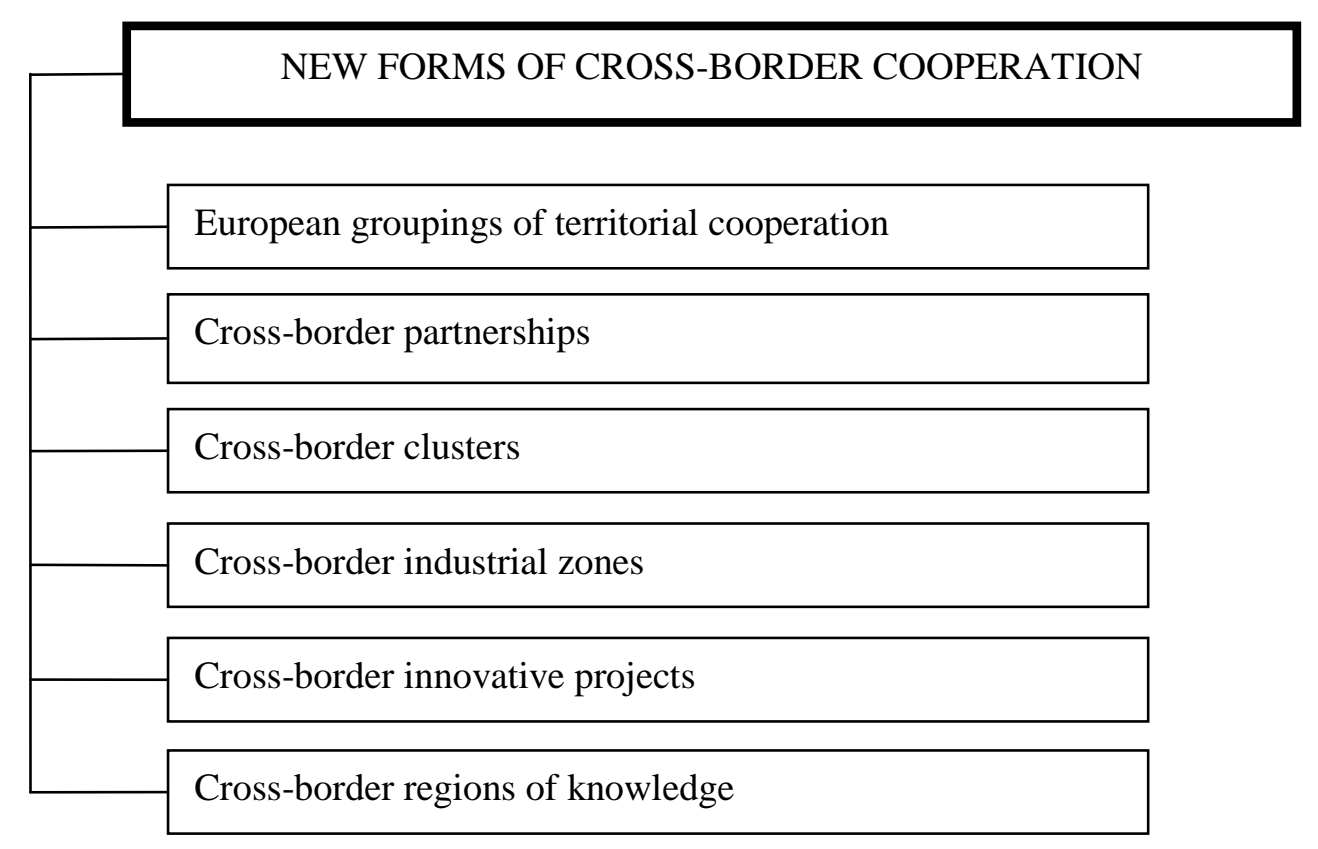

Figure 2. Classification of new forms of cross-border cooperation (developed by the authors)

Cross-border industrial zones are the zone structures, which are created in the areas of the cross-border area. There is a concentration of the human, financial, scientific and technical potential of the developed industrial base and of the industrial infrastructure. They aimed at the development of new and high technologies and at the engagement into the production various kinds of knowledge-intensive high-tech products.

The most common organizational forms of cross-border cooperation, in which both Europe and Ukraine have gained enough experience, are, in particular, the "cross-border clusters". Their further development, improvement of their operational efficiency will assist reviving the economic 
activity and stimulating the economic growth, which would positively result in the alignment of socio-economic indicators and regional competitiveness to the European standards.

Cross-border clusters cover the related border areas of neighbouring countries, which include institutions and companies located on both sides of the border. Therefore, cross-border clusters can be defined as a group of independent companies and associated institutions, which are geographically concentrated in the cross-border region. They cooperate and compete, specialize in various fields related by common technologies and skills and complement each other, which ultimately enables a synergistic and network effects, the diffusion of knowledge and skills (Figure $3)$.

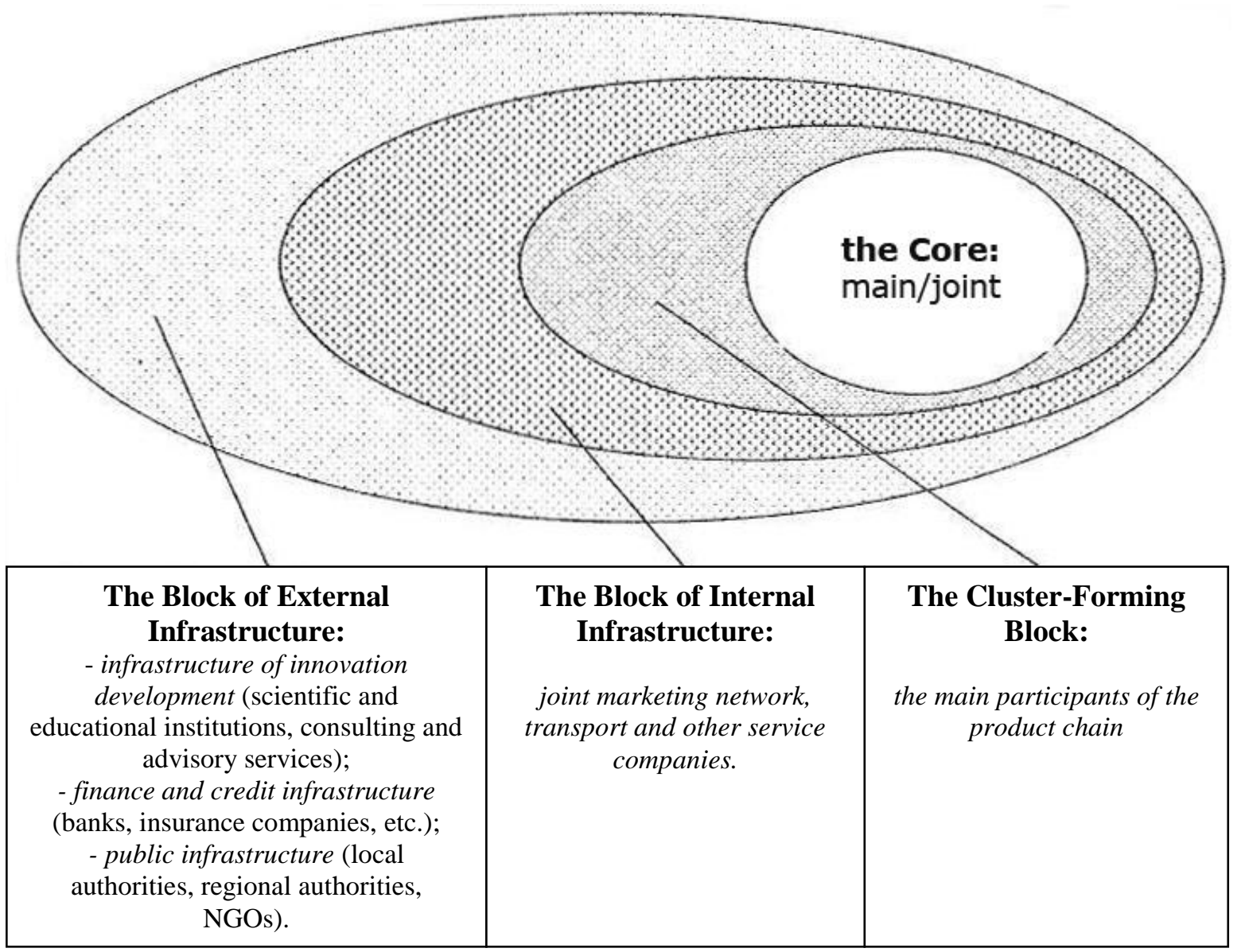

Figure 3. The Model of the Cross-Border Cluster (Sabluk, 2010)

There is the core within the cluster (the Integrator) - a leader, who initiates the formation of the cluster. Around this core began to emerge cluster-forming block - the complex of enterprises members of the cluster, which are engaged in the production of equipment, the production of tools or performing other economic activity and jointly complete the technological chain of production.

However, the presence of this main block is not enough for effective functioning. Have to be the block of internal infrastructure - the cluster members, those functions are to promote products to consumers, to provide the marketing services for sale's organizing and etc.

The next one is the block of external infrastructure, which includes: the public infrastructure - a set of entities that provide housing for living, shopping and other community facilities and cultural services; innovative infrastructure - a set of entities that provide the innovative component of the cluster: schools, vocational schools, research institutions to improve the technologies and the teaching profession; and the financial one. Building of this infrastructure provides not only by the entrepreneur, but also by the regional authorities and the local governments.

Thus, the creation of the cross-border clusters in Ukraine will improve the productivity and 
the innovation activity of enterprises that are the part of the cluster, as well as increasing intensity of SMEs, enhance the foreign direct investment, acceleration of socio-economic development of the regions of clusters' allocation. It ultimately will increase the number of work places, the wages scale, and revenues to the budgets of all levels, which will lead to the stability and competitiveness of the regional economy.

Moreover, the implementation of such forms as cross-border clusters and cross-border industrial zone among Ukrainian regions is actualized by a number of trends and characteristics, given below.

Firstly, Ukrainian regions use the potential of industrial zones and clusters (including crossborder) to a very small degree, whereas they are the main institutional components of innovation and investment model of the economic development. The policy of cross-border clusters' and industrial zones' creating was most common for European cross-border regions and, as practice shows, these forms significantly contribute to the economic development of border areas by stimulating region's innovation and investment, ensuring efficient use of its resources and creating work places in outlying areas, remote from the centre.

Secondly, the inefficient use of a euroregion as an organizational form of cross-border cooperation, whose function is to facilitate obtaining funds for cross-border projects, co-financed by EU structural funds and other international financial institutions. Thus, the activity of cross-border cooperation within the Ukrainian euroregions is defined as low. This suggests significant unused potential of euroregion that can serve as a coordinating structure for the development of crossborder clusters and industrial zones.

Thus, mechanisms of implementing the EU regional policy are aimed at supporting the development of border areas and providing the opportunities for additional funding for cross-border projects within budgets of cross-border programs. Ukrainian regions are involved in following programs: "Poland-Belarus-Ukraine 2007-2013", "Hungary-Slovakia-Romania-Ukraine 20072013", “Romania-Ukraine-Republic of Moldova 2007-2013” and "Black Sea 2007-2013".

These programs' priorities include institutional cooperation and promotion of border regions' socioeconomic development. They, in particular, support the projects of the cross-border clusters' and industrial zones' formation. However, the low activity of the Ukrainian side has led to its relatively low presence in the lists of grant funding recipients. This situation could have been forecasted at an earlier stage of ENPI (European Neighbourhood and Partnership Instrument) implementation, where, unlike other countries, Ukraine's interests were not represented properly.

Thirdly, there is no appropriate state support of innovation infrastructure (including crossborder clusters and industrial zones) in Ukraine. Unlike cross-border industrial zones, which operate within a clearly defined territory and require significant investments in infrastructure, cross-border clusters combine voluntary participants who are freely situated in the cross-border space. This makes them more affordable to implement with appropriate government support (Voloshin, 2011).

In our opinion, reforms of national legislation regarding cross-border cooperation of Ukraine should be carried out. Law of Ukraine for "Cross-Border Cooperation" defines only the basic foundations of such activities. It is essential to create a law describing such forms of cross-border cooperation as cross-border cluster and cross-border industrial zone, as well as clearly defining and regulating the activity of these forms.

It is equally important to initiate the creation of cross-border industrial zones (parks) along with the promotion of regional innovation activities in order to form a certain type of peripheral structures in the border regions. These structures would play the role of business incubators and would help investors to start the production, to create a financial intermediary in obtaining financial assistance from EU structural funds.

Using euroregion as the coordinating structure for cross-border clusters or industrial zones would be practical, because it is the institution that must work out and implement the strategy of cross-border region development. Considering that, cluster strategy applies to all strategies aimed at 
creating a favourable environment for cooperation between different stakeholders at local, regional, cross-border, national and international levels. The euroregion can and should take on the role of a "centre" through which information is exchanged and activities of cross-border cooperation between members of the cross-border cluster are coordinated.

Development and implementation of an effective, transparent project management, monitoring and evaluation of cross-border projects on the basis of clarity and accountability will allow general public participation at all stages of project implementation. For this purpose, it will be appropriate to engage leading authorities, research institutions, NGOs and EU experts in crossborder cooperation (Joint Technical Secretariats).

Providing organisational financial support to participants of international projects implemented within programs of cooperation between EU and neighbouring countries may also be vital. To ensure that, it will be necessary to transfer all power regarding the selection of projects of international cooperation to local authorities. The introduction of such financing would be possible after forming a "from below to the top" state budget and transferring the authority of forming local budgets to local communities in order to ensure their financial independence during the implementation of joint international projects, including cross-border ones.

Regional authorities and local governments should provide active support for interregional and cross-border economic cooperation and consultations for economic entities that search for partners across the border, as well as assist businesses that contribute to economic development of the region and increase revenues to local budgets. This solves the problem of limited financial resources and provides the mandatory introduction of funding for cross-border projects. It may also contribute to implementation of the preferential loans mechanisms (low interest rate) for the Ukrainian beneficiaries of EU cross-border programs in order to help them finance the required $10 \%$ of project budget (principle of co-financing).

\section{Discussion}

The done analysis allows making some conclusions and to prove mentioned above statements, highlighted below.

Using the advantages of cross-border cooperation acts as an important factor in strengthening the regional competitiveness within limited public funding for equalization of regional socioeconomic disparities on the post-crisis stage of Ukraine's economic development.

All processes of cross-border cooperation intensification are complementary, and therefore experience of inter-regional cooperation can be successfully used to improve cross-border cooperation and to strengthen the competitiveness of the Ukrainian border regions.

To solve the problem of low level of Ukrainian border regions' competitiveness, it is necessary to use such new forms of cross-border cooperation as cross-border clusters and crossborder industrial zones.

The done analysis allows determining the cluster as a geographically localized form of integration of the manufacturing interacting entities from the bank and private sectors, of academic and government institutions, of innovative businesses / organizations, which is characterized by the production of competitive goods or services, availability of a coherent development strategy aimed at the interests' realization of each participant and the territories of clusters' localization, and has significant social and economic importance for the cross-border region.

The most important instrument for the competitiveness increase of Ukrainian border regions is the European Neighbourhood and Partnership Instrument, which includes the following programs: "Poland-Belarus-Ukraine 2007-2013", "Hungary-Slovakia-Romania-Ukraine 20072013", “Romania-Ukraine-Republic of Moldova 2007-2013” and “Black Sea 2007-2013”. 


\section{References}

Amosha, O. \& Lyashenko, V. (2008). Prospects for the formation of cross-border Euroregional innovation systems and nanotechnology. Social-economical Problems of modern period of Ukraine, Vol. 3, 159176.

Andersson, T., Schwaag-Serger, S., Sorvik, J., Hansson, E.W. (2004). The Cluster Policies Whilebook. IKED.

Kish, Y. (2008). EU policy on cross-border cooperation with Ukraine after EU enlargement. Scientific Bulletin of Uzhgorod University. Series: History, Issue 20, 168-172.

Lehner, J.-P. (1995). Twelve Brief Notes on Transborder Regions in Europe. Regional Contact. No. 10., 291-292.

Mikula, N. (2004). Interterritorial and cross-border cooperation: Monograph. - Lviv: IRD National Academy of Sciences of Ukraine.

Porter M. E. (1998). Clusters and the New Economics or Competition // Harvard Business Review.November-December. - 77-90.

Sabluk, P. T., Kropyvko, M. F. (2010). Clustering as a Mechanism for Competitiveness Improving and Social Orientation of Agricultural Economy // Economy of Agribusiness. - Number 1. - 3-12.

Supreme Council of Ukraine. (2004). Law of Ukraine for "Cross-border cooperation", N45, art. 499.

Varnaliy, Z. (2007). State regional policy of Ukraine: features and strategic priorities: monograph, Kiev.

Voloshin, V., Vasyltsiv, T., Mikula, N., Borschevsky, V., Babets, I., Zasadko, V. \& Mihuschenko, Y. (2011). Mechanisms and tools take advantage of interregional and cross-border cooperation in enhancing the competitiveness of the Western regions of Ukraine, Analytical report, Lviv. 